\title{
SOME QUESTIONS ON THE BEIDI HUNS
}

Borbála Obrusánszky (a)

(a) Karoli Gaspar University. Budapest, Hungary. Email: borbala.obrusanszky[at]mfa.gov.hu

\begin{abstract}
Because of a fierce battle among crown princes of the Huns, the great Hunnic Empire was divided into two parts in $53 \mathrm{BC}$, when two brother, Huhanye [呼韓邪] and Zhizhi [郅支] fought for the throne of the Huns. The southern part led by Huhanye was submitted to the Han-dynasty. The northern part remained independent for a while, while the southern part, under the guidance of Huhanye Shanyu, concluded an agreement with the Han dynasty. The Huns received a wide ranging autonomy inside the Chinese Empire. A new situation emerged when the Han Empire weakened, from the second half of the 2nd century onward, and, instead of the elected emperors, eunuchs, and later on several warlords, who served the Han dynasty, acquired the main power, took control over certain territories of the former Han dynasty, and gradually created independent kingdoms. The Southern Huns were not able to achieve their independence from the Chinese Empire, because the great warlord Cao Cao [曹操] occupied a big part of the Empire, which contained the territory of the Huns. Right that period [3rd century CE], one significant portion of the Huns - the Beidi Huns - lived in the eastern part of Yellow River, today Shanxi province. The Jin shu chronicle [an official Chinese historical text covering the history of the Jin dynasty from 265 to 420] includes a summary account of their life and short history. I present some important details of that account.
\end{abstract}

\section{Keywords}

Beidi, Yellow river, Jin-shu, Northern dynasties, Xiongnu, Ordos, Cao Cao, Liu Yuan, Han, Shanyu

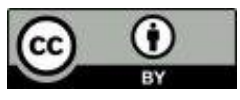

This work is licensed under a Creative Commons «Attribution» 4.0 International License 


\title{
НЕКОТОРЫЕ ВОПРОСЫ ИСТОРИИ БЕЙДИ ХУННОВ
}

\author{
Обрушански Борбала (а)
}

(b) Университет Кароли Гашпар. Будапешт, Венгрия. Email: borbala.obrusanszky[at]mfa.gov.hu

\section{Аннотация}

Из-за ожесточенной битвы между наследными принцами гуннов Великая империя хуннов в 53 г. до н.э. была разделена на две части. В этот период за трон сражались два брата, Хуханье [呼韓邪] и Чжичжи [郅支]. Южная часть во главе с Хуханье была подчинена династии Хань. Северная часть некоторое время оставалась независимой, в то время как южная под руководством шаньюя Хуханье заключила соглашение с династией Хань. Хунну получили широкую автономию в рамках Китайской империи. Начиная со второй половины II в. сложилась новая ситуация, когда Ханьская империя ослабла, и вместо избранных императоров, евнухи, а позже и несколько военачальников, служивших династии Хань, захватили власть, взяли под свой контроль некоторые территории бывшей династии Хань, и со временем создали независимые королевства. Южные хунны не смогли добиться своей независимости от Китайской империи, так как великий полководец Цао Цао [ 曹操] захватил большую часть империи, которая содержала территорию хуннов. Именно в этот период [III в. н.э.] в восточной части Хуанхэ, ныне провинции Шаньси, проживала значительная часть хуннов - Хунны Бейди. Хроника Цзинь шу (Книга Цзинь) [официальный китайский исторический текст, охватывающий историю династии Цзинь с 265 по 420 г. г.] содержит краткое изложение их жизни и их истории. В статье представлены некоторые важные детали этого повествования.

\section{Ключевые слова}

Бейди, Хуанхэ, Книга Цзинь, Северные династии, Хунну (сюнну), Ордос, Цао Цао, Лю Юань, Хань, Шаньюй

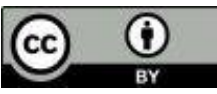

Это произведение доступно по лицензии Creative Commons «Attribution» («Атрибуция») 4.0 Всемирная 


\section{INTRODUCTION}

Unlocking that Huns did not disappear from the Asian History and rethinking the history of the Asian Huns poses a big challenge for the coming decades or centuries as well. Scholars must search and analyse the relevant Chinese chronicles, in order to find details about those tribes and states who lived in present day Northern China - Inner Mongolia, Shanxi [Eastern bank of Yellow river], Shaanxi [Northwestern part of China, edge of the steppe], Gansu [Province along the Yellow river], and others - and so to reveal their late history and way of life. In the present paper, using the chronicle most directly relevant to the subject, the Jin Shu chronicle, I deal with those Southern Huns in Chinese sources - who settled down in the present Shanxi and Shaanxi provinces and played an active role there.

Historical periods related to the Southern Huns are controversial among scholars. Colleagues who deal with history and civilisation of the Eurasian steppe claim a rapid merging of the Huns into the Chinese society from the 2 nd century CE onward, while only a few place that process in the first decades of the 3th century. Contrary to the main stream point of view which states that Southern Huns also disappeared Asia from the $2^{\text {nd }}$ century CE [Barfield, 1979; Hyun, 2005]. Several archaeological and historical summaries assert that the Southern Huns quickly assimilated into the Chinese. ${ }^{1}$ Some authors think that they disappeared from history in 216 , when Cao Cao abolished the title Shanyu and divided the Huns into five administrative units. The historiographical situation is the same regarding the Northern Huns. Most literature mentions that their state was abolished in $90 \mathrm{CE}$, when the Xianbei [Eastern neighbour of the Huns, who lived in present day Manchuria] attacked them (Grousset, 1970; Hyun, 2015; Iishjamts, 1994; Twitchett- Loewe, 1995). Based on this theory, historians argue that there is a connection between the Asian and the European Huns. However, that inference is refuted by contemporary Chinese chronicles. According to the Hou Han shu [Chinese chronicle, the translation is: History of the Late Han], the Xianbei did not attack the northern Huns in the 90s CE, but a Southern-Hun-Chinese-Xianbei coalition attacked the northern territories, and the majority of the army was formed by the Southern Huns. ${ }^{2}$ Although the attack chased away the ruling Shanyu (88-?) [His name is unknown], who escaped northward, but a new Shanyu or his brother, Yuchqian (91-93) emerged and ruled the scattered people. The state itself faced a difficult economic situation, but no source asserts that the Hunnic

\footnotetext{
${ }^{1}$ Luo emphasis that Southern Huns lived inside the Han border and had history of intergration, not assimilation (Luo, 1999, p. 442).

${ }^{2}$ The number of the attacking army could be around 38 thousands, the Southern Hun has sent 30 thousand.
} 
state was over. Moreover, the Chinese Hou Han shu reported that a new Shanyu was elected, and submitted politically to the Chinese Han dynasty in $93 \mathrm{CE}^{3}$

If we read the contemporary Chinese historical sources and publications carefully, we can find plenty of mistakes and misunderstandings regarding the history of Asian Huns, or Xiongnu, from the 1st CE onward. Some scholars who accept the old theory that the Huns assimilated to the Han Chinese, want to minimize their historical role in Inner Asia. On the other hand, the Chinese sources from the period mention the Huns (as Northern Savages, Northern Thieves, Beidi, etc.) over a time span of nearly six hundred years, from Shi Ji [Chinese chronicle from the $2^{\text {nd }}$ century $\mathrm{BC}$ ] to Zhou Shu [records the official history of the Chinese and Xianbei people. It was completed in $636 \mathrm{CE}$ ]; moreover, if we count the pre-Qin accounts and records, we can extend the written history of the Huns to nearly a thousand years. ${ }^{4}$ In order to understand what happened with the late Huns, we need to summarise their history. The above-mentioned chronicles mention the origins of the Huns, beginning with Touman (?-209 BC) and Maodun Shanyu [209-174 BC] ascending the throne until the division of the Hun Empire into two parts (51 BC). The next phase is the history of the divided Huns, mainly of the Southern Huns, who joined the Han Empire. The Han chronicles (Books of Former and Late Han) dedicated whole chapters to them (Batjargal, 2016b), but the Northern Huns also appear in the chapter on Western Regions. 5

We can find evidence that the Huns - both Northern and Southern did not disappear, but that they contributed to the historical events of the first half of the 2 nd century $\mathrm{CE}$.

Since the second half of the 2nd century, the Han Dynasty weakened, and instead of the elected emperors, the Eunuchs took control of the whole country. The ultimate weakening of the empire and its split into parts were caused by the rebellion of the yellow turbans. At that time some warlords, or great military leaders of the Han dynasty, seized regions and established their own government and administration, and gradually formed independ-

\footnotetext{
${ }^{3}$ He got state seal, four jade swords and one chariot from the Han court. Hou Han shu 89. (Batjargal, 2016b, p. 53). The Northern Huns weakened in the end of the 1st century AD and did not threatened the border of Hans, there is no records about them. But the Hou Han shu mentions them in the middle of 2nd and 3rd century CE. Later, the Bei shi also recorded that remnants of Xiongnu or Huns lived both the western regions and north, neighbouring the Dinglings. Hyun 2015 also mentioned that Northern Huns remained in Altay region until the 4th century CE, and Southern Huns stayed in Ordos. Regarding the Late Huns L. Bei Si 97. juan. "The remnants of the Huns live from the north-westward to Juanjuan» (Csongor, 1993, p. 21).

${ }^{4}$ There plenty of Pre-Qin historical sources. Bamboo annals, Lun Yu, Zuo Zhuan, etc.

${ }^{5}$ Hou Han shu 88. L. Hill, 2004. In: http://depts.washington.edu/silkroad/texts/hhshu/hou_han_shu.html
} 
ent kingdoms. By the end of the 2nd century, the Eastern or Late Han Empire was disintegrating into chaos. In spite of these developments, the biggest warlord Cao Cao occupied almost the entire part of the Empire. He established the Wei or Cao Wei [220-266] state, whose successor state became Jin [266-420]. The Xiongnu and the rising Xianbei took advantage of China's weakness and acquired territories in the northern ad north-eastern part of the Former Han-dynasty.

\section{SOUTHERN HUNS IN THE 3RD CENTURY}

The history of the late Southern Huns was summarised by the Book of Late Han or Hou Han shu, edited during the Wei period, or the middle of the 5th century. Chapter 97 of the other relevant source, Jin shu, concerns the Beidi Huns: with a brief summary of their origin and deeds and what happened to them after Huhanye joined the Han dynasty and of their division into parts, and a description of their titles and tribes.

The era of the Beidi Huns, or the 3rd through the 5th centuries, was a special period in the River Yellow bend region because, following the collapse of the Han dynasty, non-Chinese peoples reigned in present-day northern and central China. ${ }^{6}$ Among them was one influential power, the Huns, who were able to obtain independence since the beginning of the 4th century, and united present-day Northern and Central China as well. So, the Chinese sources prove that the Hunnic state did not disappear from history. On the contrary, the Huns got stronger between the 3rd and the 6th centuries.

As the Book of Late Han also refers to the fact that the royal clan, $\mathrm{Xu}$ Luanti [Royal line of the Huns] family, remained dominant in both parts of the Northern and the Southern parts of the Huns. ${ }^{7}$ There is a special exception, the Northern Liang [Kingdom of the Huns between 397-440/460] Dynasty, whose king did not originate from the royal Hunnic clan. He was only a high-ranked nobleman, a wang who gathered and united those Hunnic tribes that lived on the southern and south-western side of Yellow River. ${ }^{8}$

On the basis of Book of Jin, Wei and Liang [Chinese Chronicles of Jin, Northern-Wei and Liang dynasties], we find that the Huns were able to preserve their independence until the 430s, when the attacking Xianbei army, or the Northern Wei [Xianbei state 386-535] Dynasty, invaded their headquarter and occupied their land. Despite these events, the Huns did not

\footnotetext{
${ }^{6}$ The period has two kinds of names: Three Kingdoms and Five Barbarians 16 Kingdoms.

${ }^{7}$ Jin shu, Hou Han shu.

${ }^{8}$ Juqu: Xiongnu surname derived from the official title. (Xiong, 2009, p. 273). Lushuihu: Ethnic group that branched off the Xiongnu. (p. 349)
} 
disappear suddenly; instead, they lost the chance to live in an independent state. They still lived in the Ordos and in the former lands [The northern belt of present China: Inner Mongolia, Shanxi, Gansu, some parts of Shaanxi and Xinjiang provinces. ] today comprising Inner Mongolia and Gansu and Xinjiang [The westernmost province of China] provinces. Some scholars believe that the Southern Huns did not disappear until the 6th century, and that a subset of them played a major role in the establishment of the Northern Zhou Dynasty. ${ }^{9}$

And now, I present some details from the Jin Shu record. The first debated question is the origin and the earliest, ancient history of the Huns. On this subject, the record contains the same statement as did the earlier historians. ${ }^{10}$ While I do not wish to address the subject here, let me note only a few historical results related to it, in order to shed light on the subsequent course of the history of the Beidi Huns. At present, three major theories are accepted by scholars all over the world on the origins of the Huns (LeeLinhu, 2011, p. 193.). Among them, two concern our topic. The first theory puts the earliest centre of the Huns in Northern China, including the Ordos. Chinese scholars, Ma thinks they came from the territory of present Shaanxi Province (Ma, 2004). ${ }^{11}$ Mongolian archaeologists say that the Huns originated from the Bronze Age cultures of Mongolia and Inner Mongolia (Turbat, 2013). The archaeological evidences are supported by Chinese written sources, which record that the Huns had lived in those regions for a long time. Not only the above presented Shi Ji or Historical records, but the Jin shu chronicle also contains a summary report of where the Huns had come from:

"The Huns are generally called Beidi. The Hun area borders on the south with the Yan [ancient Chinese state 11-3rd century BC] ${ }^{12}$ and Zhao [Ancient Chinese state 403-222 BC] ${ }^{13}$ countries. The northern part is desert, ${ }^{14}$ their neighbour Nine

\footnotetext{
${ }^{9}$ Yuwen Hue (542-557) he was the founder of the dynasty. Crespeny mentions he was Xiongnu or Hunnic origin (Crespegny, 2006, p. 655).

${ }^{10}$ The chronicle was edited in 648, in the period of Tang dynasty. They used the ancient documents. Fang Xuanling, the Chancellor of the Emperor Court has supervised the editing work. It contains some important chapters, which mention Southern Huns. The Chapter 101-105 recorded the history of Liu clan, who established a dynasty in Yellow-river bend. The chapter 129 mentions life and activities of Juqu Mengxun, who founded the Northern-Liang dynasty in the end of the 4th century. The chapter 130 mentions Helian Bobo's life. He was the founder of the Da Xia dynasty.

${ }^{11}$ They think that one ancient settlements of the Huns located the western part of Shaanxi province. LeeLinhu also states that.

${ }^{12}$ Ancient state, which is located in Eastern Inner Mongolia, surroundings of Beijing, and some parts of Manchuria.

${ }^{13}$ Ancient Chinese state. It is located in Shanxi, Hebei province.

${ }^{14}$ It may refer the part of Gobi, which is not totally desert, only a few percent of it.
} 
$Y i$ [Non-Chinese people, who lived northern part of Chinese states] ${ }^{15}$ in the east, and in the west by six Rong-s [Non-Chinese people, who lived in the western part of Yellow river]. From generation to generation, they have chosen their rulers and officers from among each other, but they do not follow Chinese customs. In Xun zhou [maybe Shang or Yin dynasty period 18-11 th century BC] and in the Yin [the other name of Shang dynasty] era the Huns were called as guifan, ${ }^{16}$ in the Zhou period [1045-776 BC] era their name was xianyun and they became xiongnu during the Han Dynasty period. Sometimes they grew stronger, sometimes they weakened and declined (Watson, 1961), but they always insisted on their habits while respecting other people, all of which has been recorded in earlier sources.",17

The earliest Chinese written documents mention some strong northern tribes. One of them could be the ancestors of Huns, because the paragraph above summarises the history of Huns, not other people. Similarly, Sima Qian, the great Chinese historian, recorded in his chronicle, Shi Ji in the $2^{\text {nd }}$ century BC, that Maodun's or Hunnic royal clan derived from the Xia dynasty [Ancient dynasty in the Yellow river region, 2200-1800 BC ], which is not surprising, since many dynasties dominating China were of foreign origin. Here is a summary: "The ancestor of xiongnu clan was a descendant of the Xia royal family, Chunwei [The last emperor of the Xia-dynasty around $1800 \mathrm{BC}]$. Already before the times of the Yao and the Sun Emperors, there were shangrong [Non-Chinese people in the western regions of the Yellow river], ${ }^{18}$ xianyun [Ancient name for the Huns. According to Chinese linguistics, as Wang Li, the pronunciation of the word is the same with Huns] and xunyu [Ancient name for the Huns] peoples who lived in the north and followed their animals from one area to another» (Watson, 1961) ${ }^{19}$. Not only the Chinese historians, but the Huns themselves kept in their memory, as the ancestor of the Huns, the Great Yu, founder of the Xia Dynasty. That was one reason - according to Jin shu, chapter 130 - that Helian Bobo [Shanyu of the Huns. 407-425] named his own dynasty and

\footnotetext{
${ }^{15}$ The classical Chinese texts as Shu Ji mentions nation yi and writes it as a man with bow. The nine Yi can be found in the Lun Yu book, which summarises Gong Zi's teachings. He wanted to live among them. Lun $\mathrm{Yu}$ 9.14. In: http://www.acmuller.net/con-dao/analects.html http://www.acmuller.net/condao/analects.html

${ }^{16}$ The name guifang is a name of the northern tribes, who fought with Shang-dynasty between 16001046. BC. The Chinese historians identified them with xianyun and xunyun, and recorded that they were ancestors of the Hun. The name itself is a composite word, where gui meant „ghost or demon”, and „fang” means ,place”. The meaning of the expression means: „the place of demons/ghosts”.

${ }^{17}$ Perhaps, it is an extract of the ancient Chinese chronicles. The Hunnic and the Chinese customs and customary laws were totally different as Sima Qian recorded it. The Southern Huns preserved it, did not accept the Chinese one.

${ }^{18}$ They are a strong horsemen alliance who lived in Northern Hebei, surroundings of Beijing, etc. The Chinese archaeologists identified their graves. The objects were similar to the Ordos-Xiongnu bronze culture.

${ }^{19}$ Shi Ji 110. L.
} 
country Da Xia [The name of the Southern Hunnic state. It was established by Helian Bobo. It existed between 407-431], in other words, the Great or the Ancient Xia.

Chinese historical sources e.g. oracle bones mention xunyun tribes or people in the Shang dynasty, while the xianyun tribes or people lived in the Zhou dynasty period. Various names existed for describing the Huns, because there was no united kingdom in China at that time and the small Chinese kingdoms created their own expressions for the Huns, but Chinese linguists inform us that the above names have the same pronunciation „Hun or Hung” - which sounded like the later expression Xiongnu (Wang Li, 1962), and acquired the special characters, 'xiong', for the Huns. The first record of using the new expression of xiongnu is only from $318 \mathrm{BC}$, when the unifying Chinese kingdoms began to use that version of the word, after which time this name spread across the kingdoms. Moreover, the first unified Chinese Empire, the Qin also accepted that name. However, other early names related to the Huns remained in use, such as bei di [Translation is: Northern Di, or non-Chinese people], xunyun, lu [slave], hu [Chinese word: beard. It has the same meaning as Barbarian in Greek-Roman world], and others. ${ }^{20}$ The Hou Han shu refers to the Northern Huns as ,northern savages» (Batjargal, 2016b). ${ }^{21}$

The above mentioned historical records, which describe the northern horsemen, give a very concise summary of the history of the Huns, and tell us that they sometimes united and sometimes split. Sima Qian summed up that history as follows: "More than a thousand years have passed from Chunwei [or the last Xia ruler] to Tou-man's [Shanyu of the Huns during the $3^{\text {rd }}$ century $\mathrm{BC}$ ] domination, during which time the tribes were divided into several groups, their numbers sometimes increasing. So it is impossible to give an account of the descendants of the Hun leaders." ${ }^{22}$ Because the Huns had no strict law for succession to the throne, the crown princes fought for the throne and it was the main reason for the division of the empire. Then, in turn, a talented ruler could unite the tribes again. In fact, many renowned sinologists also mention the impact of such talented Hun rulers on early Chinese dynasties. The Jin Shu chronicle gives a very concise situation report on the causes of the split of the Hunnic Empire, which was caused by a war among Hunnic crown princes. Both Hou Han shu and Jin shu report that Huhanye [Shanyu, 53-31 BC] joined the Chinese Han

\footnotetext{
${ }^{20}$ According to Uchralt, the early Chinese pronunciation of the name could have been the same as that of the later Xiongnu, which was in the BC.

${ }^{21}$ Hou Han shu 89. It is rather similar to Bai Di or White Di tribes, who lived around 6-5 th centuries BC. They were one of the strong northern horsemen.

${ }^{22}$ Shi Ji. 110.
} 
dynasty, and Hou Han shu mentions that the Shanyu grazed in Wei River ${ }^{23}$ area, and when he held sacrifices or ceremonies, the whole river bend was full of horses (Batjargal, 2016b). Jin Shu designated the old Bing Province as the centre of the Huns where the Han Dynasty resettled. The eastern province of Yellow River, today Shanxi province, was the buffer zone between the two empires. The famous Battle of Baideng [near today's Datong] $]^{24}$ in $200 \mathrm{BC}$ took place in this zone, where the Huns encircled the Han Emperor. This special zone was important for the Han dynasty, as they wanted to defend Chinese inhabitants from the Northern Huns, who had threatened that region severely. Later on, the other Northern tribal confederation, the Xianbei [Non-Chinese people, who occupied Northern China during the $3^{\text {rd }}$ century], who had expanded westwards, posed a threat to both the Han and the Huns, and so the Han and the Huns were also trying to stop them at the eastern part of Yellow River.

The history of the Southern Huns in the 3rd century AD is missing from most publications, apart from papers related to Sinology. The reason is that most scholars think that the Huns had already disappeared from history by that time. But Jin Shu chapter 97, wrote down their deeds and it did not seem to disappear from history. Moreover, the Chinese officials had a fear that the Huns would grow strong and unite the tribes around them, so they tried to divide the Huns. The Huns lived close to the Chinese capitals, Changan [today Xian, ancient capital of China] and Louyang [Ancient capital of China. ], and they were able to invade and rob those cities at will, and devastate the surrounding settlements. The most significant attack was in 195, when they invaded Changan and kidnapped a poet, Cai Yan [famous woman poet of the Han-dynasty. ], who became the consort of the left wise king. She stayed there for 12 years and General Cao Cao could evict her from the hostage. The declining period of the Southern Huns was connected to General Cao Cao, who had proclaimed himself as king of Wei in 216. One of his first declarations eliminated the unity of the Huns, because he was not the ruler of the Han and was not bound by the agreement between the Han and the Huns. ${ }^{25}$ The basis of a hostile relationship was the Huns fought against Cao Cao and supported another warlord at the very beginning of the 3rd century. That's why Cao Cao wanted them to disperse.

In 216, Huchuquan Shanyu travelled to Cao Cao court in Ye to receive the nominal title. ${ }^{26}$ Cao Cao did not allow the Shanyu to go home, so

\footnotetext{
${ }^{23}$ The river is located in the southernmost part of Ordos.

${ }^{24}$ Baideng is located in the eastern part of Datong city. (Shanxi province, China) The Chinese authority created a monument.

${ }^{25}$ Barfield 1979. He summarised the agreement between the two parts. About Cao Cao policy towards the Huns: (Crespigny, 2010).

${ }^{26}$ Present day Handan, Hebei province.
} 
the Shanyu remained in captivity and died in Cao Cao's court. After his death, the title Shanyu was abolished. Although the Cao Cao administration weakened the Huns it does not mean the end of the southern Hunnic state. After that Cao Cao created a new administrative unit, so that he divided them into five parts, and settled them on the left bank of Yellow River. The Jin shu recorded this event as follows: „The eastern provincial du wei [official title of the Huns] led more than 10,000 households and was based in Zhen [Eastern part of the Yellow river] District. ${ }^{27}$ The southern provincial officer of the du wei led 3,000 households and lived in Pu zi [Southern part of the Yellow river] country. ${ }^{28}$ The du wei officer in the northern province led 4,000 households and lived in Shin shen yan [Unknown place]. The head of the centre of du wei was headquartered in the middle of the country, led 6,000 households, and lived in Da Lin [Somewhere in present day Shanxi province]" (Batjargal, 2017) ${ }^{29}$. This summary does not mention the disappearance of the Hunnic state, but merely describes new divisions of the Huns, and proved that the Huns continued to live in an organized framework.

Cao Cao himself did not want to do that: in place of the Shanyu, he appointed a Chinese official to control the Huns. Regarding Cao Cao ordered him to rule over the north partition of Pingyang Xiongnu as Tiefu Right Virtuous King Qubei [Leader of the Southern Huns, 260-272], or the western wise king to lead his own people, but placed a Chinese official above the Huns. They wanted to prevent the Huns claiming independence from the Chinese. The Chinese chronicle mentioned that, "In the time of Wu Di [Title of the Chinese Emperor], the commander of the equestrian army was Qiang Xie [personal name] of the Du [or commander ] Officer Qi $\mathrm{Qu}$ [personal name]. They put their own people among the Huns to keep them under control. It seems that there was a Hun person who reached the highest, duwei dignity"(Batjargal, 2017). We also find the report that, "In the province, venerable people have been appointed leaders and elected by the Chinese, who were smooth officers to oversee them. At the end of the Wei dynasty, these leaders were replaced by du wei.

Despite Cao Cao's decrees, the Huns did not weaken, but grew stronger and proliferated in the new threat. The Jin shu described the transition as follows: "Many years passed and households multiplied. The northern areas were full, and they could not stop it by decrees. At the end of the late Han Dynasty, riots began, and many officials said that, 'The Huns are very

\footnotetext{
${ }^{27}$ It is probably the modern Xin zhou district in the central part of Shanxi province.

${ }^{28}$ It is probably the modern Xixian district in Shanxi province.

${ }^{29}$ Jin shu 97. It was the centre of Bai Di or White Di in the pre-Qin period.
} 
cunning. They've become robbers and threaten us. It is good to be cautious ahead of time!'”(Batjargal, 2017).

The fearlessness of the Hunnic overpopulation was a real threat from the Chinese perspective. The Huns remained in their former territory of Inner Mongolia and in their resting place, the present-day Northern China, but in addition they appeared in the Central Plain, which was the motherland of the Chinese people. The Chinese inhabitants of the cities of the Silk Road escaped from there and looked for better places to live. The Chinese population decreased. After the collapse of the Han dynasty came the turmoil and wars of the Three Kingdoms, in which period the population diminished to 25 million by $280 \mathrm{CE}$, although it may have been as low as 16 million - an apparent loss of 30 million (Marks, 2011, p. 106). Those affected Chinese were successors of Chinese farmers who had been resettled in the western part of the Yellow River and beyond by Emperor Wudi [title of the emperor] to defend the northern access to China. ${ }^{30}$ So, the Chinese people left the sparsely populated lands of former Yuezhi [western part of the Yellow river] and Hunnic lands, and moved to the Yangzi [southern part of today's China] valley and the south coast, the present-day Fujian [South-China] and Guangdong [South-China]. Parallel to that migration, northern tribes or groups of Huns settled down in those places, meaning that the ethnic proportion changed, and the so-called "northern people" or Huns attained a demographic majority.

Not only did the Southern Huns multiply, but the Northern Huns, who had suffered from natural disasters, also asked for admission into the empire, beginning in the 1 st century CE. The History of Southern Huns narrated in the Hou Han shu and Jin shu also mentions migrations. Northern Huns were often decimated by natural disasters, depletion of fauna, or migration, and some tribes asked for subjection to the Han empire. ${ }^{31}$ The Jin shu mentioned the following:

After Wu Di was seated on a throne, the Huns who lived outside had a great flood, and so the sai ni ni [name of the tribe], the he nan [name of the tribe], and other tribes - more than two tumen (or 10,000 households) - submitted to China. The Emperor welcomed them and deployed them to the old Yi Yang [somewhere in Shanxi province $]^{32}$ town on the right bank of the river. Later they joined the nations of the Jin [Chinese state 266-420] state. Ping yang [Centre of the Beidi

\footnotetext{
${ }^{30}$ Hou Han shu 88.

31 Thousands of Northern Huns moved to the Han-dynasty around 91 CE. (Twitchett- Loewe, 1995, p 405; Batjargal, 2016a, pp..89-90). According to Hou Han shu, the Northern Huns have joined the Southern Huns, not Xianbei.

${ }^{32}$ The name of a place near Louyang, the former capital of the ancient Han dynasty. It is between the Yellow and Luo rivers.
} 
Huns], Xi He [Linfen], Tai Yuan [capital city in Shanxi province], Xin Xing [part of many of the prefectures of Le Pin, all lived well."

In Tai Kang's period (280-289), tens of thousands of people also requested admission to the Three Kingdoms. ${ }^{33}$

However, the literature suggests that the population of the former Han Empire dropped dramatically prior to and until 280, especially in the northern region. ${ }^{34}$ So, despite the old theory of the Huns' rapid assimilation to the Han Chinese, the relevant historical records present that the number of the Huns increased greatly in the late Han dynasty and during the Three Kingdom period. The ancient Chinese capital, Changan - or, more precisely, the northern part of the city and the region of the Wei River, which belonged partly to Ordos Pleatue, settlements of non-Chinese people. This part of the city and the river region were suitable for keeping flocks. In Guangzhong [city], today's Shaanxi Province, contemporary sources report that about half of the population was not Chinese (Liu, 2001, p. 4). ${ }^{35}$ During and after the Three Kingdom period, not only Huns, but the Qiang [Ancient Non Chinese tribe] and the Di [Ancient Non Chinese tribe] people also resettled there (Twitchett-Loewe, 1995, pp. 426-427). The situation did not change even in the middle of the 5th century. This was the reason for the Northern Wei Dynasty relocating not to Changan, but to Luoyang. In General Lu Si's biography, we can find the following explanation: "Changan City and its surroundings are in danger. The people there are wild and hardy...» (Liu, 2001, p. 9). The fears that the Huns rebel against the Chinese was a real danger. The chronicle Jin Shu records the rebellion led by a certain Meng [Hun], and reports the following: "There is the qi mu [name of the tribe] tribe and the le [tribal name] tribe in their country. We are all strong people. They are rebellious» (Batjargal, 2017). The Chinese were only able to defend themselves against the rebellions by altering their population, so they sought to break the power of the Huns and reduce their numbers. However, that approach was not sufficient to stop the horsemen. ${ }^{36}$

Not only the late history of the Huns or the Xiongnu, but also their social organisation, is a debated question among scholars. Some question the

\footnotetext{
${ }^{33}$ Tai Kang's fifth year the Hunnic A hou tribes alliance lead by Hu tai with two ten thousand armies joined China. In the seventh year, Hunnic Hu du da bo and Lou sha hu submitted people to China, whose number exceeded more than 10 ten-thousand and Wei zhou $\mathrm{Ci}$ shi officer at Fu pon wang prefecture submitted to China. The next year the Hunnic dudu official together with Da Dou Do Yi Yu clans also arrived and submitted to China with two ten thousand cattles and ten thousand ships.

${ }^{34}$ The population of the Han Empire was 56 millions in the middle of the 2 nd century CE, it reduced 20 millions in the end of the 3rd century CE. (Marks, 2011, p. 106)

${ }^{35}$ The Huns settled down there mainly in the period of Later Zhao-dynasty. (319-329)

${ }^{36}$ The Wei army settled down four ten-thousand or 40.000 families there and filled the territory with other ones. Their descendants did not rebel against China.
} 
existence of a Hunnic state, despite plenty of evidence (Sneath, 2007). Others place the process of state formation relatively late, or in $209 \mathrm{BC}$, when Maodun became the Shanyu. We will probably never be able to set an exact date for the establishment of the Hunnic state, but the sources clearly claim that the Huns had a state, named 'guo' in Chinese - like the Chinese state. The terminology means that the authors knew that the Huns were not a headless organisation, but had a very strict administration. From a historical point of view, it is more accurate to say that when they appeared in the Chinese sources, Maodun's ancestors already had a well-organized state formation. The first detailed description was given by Sima Qian in his chronicle, who wrote not only about the leaders of the Hunnic administration and Hunnic dignities, but also about the nature of the state. He listed the great Hunnic holidays and customs, and even some special laws of the Huns. Chinese chronicles report that the Huns lived in a specific territory and were divided into tribes, each leader being responsible for his own area. ${ }^{37}$ It was an important observation that the Huns insisted on possessing their own land, which was the foundation of the state. ${ }^{38}$ Probably, as with later nomadic peoples, the owner of the whole country was the state and the tribes lived on it and divided the pastures. The Shanyu appointed the local administrative leader among the Huns in order to coordinate tasks and duties. Decimal or ten system was one characteristic achievement characteristic of the steppe; it was the crucial part of the central administration of Shanyu, a system that stood above the local tribal self-governmental system. State dignities were inherited; one such dignity was guduhou [Hunnic official], which is a subject of the Hou Han shu chronicle (Batjargal, 2016b). ${ }^{39}$ Those who refused to accept the Shanyu's decrees or betrayed the state or the Shanyu, were removed from office and replaced. Chinese sources mention that the most important leadership positions - such as the wise king and the luli wang [the deputy of the wise king] - were held by members of the Hun ruling clan. The Shanyu appointed their sons and relatives for these highest positions. Boodberg considers the names of the Hunnic dignities to be expressions for kinship (Boodberg, 1979, p. 5). Unfortunately, Jin shu does not mention the governmental or administrative system of the Beidi Huns and the Da Xia [407-431] Empire, as earlier sources had done. Shi Ji and Hou Han shu record information on the three great festivals of the Huns, when they convened a parliament to discuss state affairs and held ceremonies (Batjargal, 2016b). Hou Han shu also ex-

\footnotetext{
${ }^{37}$ Shi Ji 110. The system remained intact later also. Mongolians, Hungarians, etc. steppe people inherited that customary law.

${ }^{38}$ Chronicum Pictum 24 says: If the land, the grass and water is theirs, all of them are theirs."

${ }^{39}$ Hou han shu 89. According to the source, each wing had the guduhou title.
} 
plains that the Hu Yan [leading Hunnic clan] tribe was responsible for the eastern duties of judge, but that the Lan [leading Hunnic clan] and Xubu [leading Hunnic clan] tribes received the western wing for the same purposes (2016b). In comparison to this material, the Jin shu chronicle is very laconic, and has little information on the structure of the Hunnic state. The author does not write about legislation and judgments, and we do not know about the ceremonies of the Huns of that time. However, it lists the names of the nineteen leading or influential clans known at that time: the government

"is divided into strains of Beidi. Inside the boundaries, there are: tu ge, xian zhi, kou tou, wu dan, chi le, han zhi, he lang, chi sha, yu bing, wei sha, tu tong, bo mie, qiang liang, he lai, zhong qi, da lou, yong qu, zhen shu and li zhie - nineteen clans in total. They do not marry among each other. The Tu Ge clan is the first. The Shanyu comes from there and leads the tribes...» (Batjargal, 2017).

According to the steppe customary law close relatives did not have the right to marry each other, which is why the Huns memorised their family trees across seven to nine generations. The importance of this sentence is that the Huns did not forget their ancient customary law; thus, they did not assimilate into Han society, but kept to their ancient rules. However, the numbers of the clans are too high for their members to have all been each other's relatives. Exploration of the tribal names in the above list is still awaiting; in some cases, we only rely on assumptions. For us, determining the identity of the leading clans may be essential.

The Hou Han shu chronicle says that Xia Luanti [leading clan of the Huns] was the name of the Shanyu's clan - a name which Uchralt reconstructed linguistically (Uchralt, 2015, pp. 219-235). The Jin shu states that the Shanyu came from the Tu ge [Hunnic clan] clan, but this could be a mistake. It is likely that $\mathrm{Tu}$ ge is not a name of the clan, but a title expressing high rank - wise, or tuqi [wise in Hunnic language] - the highest dignity after the Shanyu. The left wise king was the title of a crown prince. Sima Qian mentioned the meaning of the title in his book. Apart from Jin shu, other Chinese sources provide the following list of leading Hun kindreds:

“...Hu Yan, Fu, Lan, Zhao [four leading Hunnic clan] (Batjargal, 2017). Hu yan is the highest among them. There are the eastern ri zhu wang [official title of the Huns], the western ri zhu wang. They help each other. The members of the Fu tribe serves as eastern zhu qiu [official title of the Huns] and the right zhu qiu. All are strong and brave. Members of the Lan tribe are the supervisors of the western and the eastern settlements. The members of the Zhao tribe are the eastern du hou [official title of the Huns] and the western du hou. There are mixed names, such 
as che yan [Hunnic tribe], zhu qiu [Hunnic tribe], yu di [Hunnic tribe], etc. They show similarities to the titles of Chinese officials." (Batjargal, 2017)

The Hu yan tribe already appears in Sima Qian, and later the Hou Han shu also mentions the tribe in connection with regarding the Han-Xiongnu war [121 BC-150[CE] for the Silk Road (Batjargal, 2017, p. 27). The Lan clan was also recorded in both historical chronicles. The Hou Han shu says they had a right to marry with the Shanyu clan. The name of the Xubu clan appears only in Shi Ji and Hou Han shu; later on, this clan is referred to as the clan of the Southern Huns, but the Jin shu no longer mentioned Xubu (2017). Was it possible to get out of the leading clans? If they rebelled against the Shanyu, or committed crime, it was possible to remove them from power (Chronica Pictum, 1976, p. 6). Jin shu mentions two new leading tribes, Fu and Zhao, and other tribes: "In their country, there are the qi mu [Hunnic tribe] tribe and the le [Hunnic tribe] tribe" (Batjargal, 2017). Moreover, there were other notable Hunnic tribes in the He Dong area [Eastern part of Shanxi Province, China]. One of them was Yuwen [Hunnic tribe] (Crespigny, 2006, p. 655). Thus, we can observe that over time the list of leading tribes was replaced. Most researchers who deal with the state administration of the Huns do not pay attention to the changes or reforms, although the historical accounts mention different titles over the span of nearly 500 years. It is likely that some reforms took place there, but the Chinese sources did not record them. The Huns had to modify the administration system because they met new challenges. Jin shu does not follow the process of alteration of the administrative system, but it can be seen from the office titles that the division of the empire into three parts remained: the middle belonged to the Shanyu, the left wing was the territory of the crown prince (who was the son or brother of the Shanyu), and the right wing was directed by a man from the Shanyu's clan. The left wing was the most advanced, and so it was listed first. These three areas followed the territorial transformation of the Hun state. While at the time of the Great Hunnic Empire the eastern province stretched through Korea, in the period we are concerned with, the 3rd century CE, it was submerged into a part of the present-day Shanxi province, or the left bank of Yellow River.

According to customary law, the eastern wise king was still the highest rank, and was usually appointed as Shanyu, ${ }^{40}$ but only restricted people acquired the right to have that office: the brother or the eldest son of the

\footnotetext{
${ }^{40}$ Jin shu: „The eastern wise king is the highest title. The crown prince is appointed there.” The same is: Hou Han shu 89. (Batjargal, 2016b, p. 35; Watson, 1961). The same system would operate among the European Huns, where the crown prince got the eastern wing or the territory between Tisa-and Don rivers. L. (Obrusanszky, 2016)
} 
Shanyu. In Hou Han shu we find some examples of how Shanyu's son or brother was elected. The Chinese chronicle contains good expressions for the eligibility for that election: „It was worded as follows: 'based on the brother's right' or 'based on the son's right'" (Batjargal, 2016b, p. 35). However, the customs of the Shanyu's election and the right to the throne did not change during the period of the Southern Huns: later on, the Shanyu's brothers and sons were to fulfil the highest dignities, so that the right to lead the empire remained inside the family.

The status of the Hunnic state was also modified during the above mentioned period, from the 3rd century BCE to the 3rd century CE. Sima Qian was the first to describe how the united, large Hunnic state operated in the 3rd and 2nd centuries BCE. In the subsequent phase, the great empire fell apart into two parts, of which the northern remained independent, but the Huns led by Huhanye were surrounded by the Chinese Han Dynasty (Batjargal, 2016a, pp. 120-121), a development that posed a serious change for them. However, the Huns and the Hans concluded an agreement regarding their mutual rights and obligations, to which they referred later. ${ }^{41} \mathrm{Be}$ cause of their accession, the southern Huns renounced their independence; however, the Chinese party granted them autonomy, and the ruler was allowed to retain the Shanyu title. According to the agreement concluded by Huhanye with the Han Emperor, the Shanyu retained the right to govern those Huns and bow-stretching people who lived outside the Great Wall (Batjargal, 2016a). The Shanyu also had the right to keep the supreme power above the Huns, but in fact the Southern Huns became vassals of the Han dynasty, and so the Shanyu lost his freedom Despite the transition of the Hunnic settlement and of the status of the Hunnic state, some publications have analysed the administration of the Southern Huns, and have claimed to discern a continuous, standardized state administration of the Huns (Pritsak, 1954). The subsequent, brief records demonstrate that two centuries later the Huns lived under Chinese rule, so they were still not independent. The titles and ranks mentioned in Book of Late Han are not likely to have been really functioning ones, because the record describes only sacrifice, not state administration. That record concerns how to sit, and what positions the nobles were to assume, in the ceremonies. Who knows whether six horns or four horns were real titles of the leaders, or served as details related to sacrifice? (Batjargal, 2016b). The first possibility is doubtful, because no other Chinese sources mention those ranks or titles of the Huns.

\footnotetext{
${ }^{41}$ The agreement was concluded by sworn brotherhood. In: (Batjargal, 2016, p. 117; Obrusánszky, 2016).
} 
We can also find similarities in the titles reported in Sima Qian's chronicle and in Jin shu, but there are differences as well. While Sima Qian refers to tuqi wang [wise king of the Huns], luli wang [deputy officer of the wise king], da jiang [great general], or to great generals - da dou wei [big commander], da tang hou [Hunnic official], and gudouhou [official, who responsible for the juristical deeds] - the Jin Shu mentions some different names. The Jin shu does not report commanders of the 10,000, but lists other titles: the left and right luli wang, who was the second most important leader, ranked after the wise king. Those are followed by a series of other titles: western yu lu wang [Hunnic officer], eastern yulu wang, eastern cang shang wang [Hunnic officer], western cang shang wang, eastern shuo pang wang [Hunnic officer], western shuo pang wang, eastern du lu wang [Hunnic officer], western du lu wang, eastern xiang luo wang [Hunnic officer], western xiang luo wang, eastern an le wang [Hunnic officer], western an le wang, and others - adding up to a total of 16 dignities. All of them are described as filled by the Shanyu's sons and brothers." 42 Unfortunately, these dignitaries are still awaiting additional explanation and research, but what we can notice is that the bureaucracy increased in comparison to the past, when a small area was led by 16 leaders. The basic arrangement - the triple division of the wings - remained. That continuity means that, during the dependency on the Han, the Huns were able to preserve their core administrative system.

\section{CONCLUSION}

The short summary concerning the Beidi Huns in the Jin shu is very useful for the research of the Southern Huns during the 3rd century. It shows how Huns fought for their independence in the total hopelessness period, and how they kept their ancient steppe customary law in a foreign environment. It also sheds light on how they later achieved their goals in 304, when Liu Yuan was able to establish an independent Hunnic State in the territory of the former Han dynasty.

\section{References}

Batjargal (2016а). Хан улсын бичиг. Хүннүгийн мастир. 94. (Batjargal, Trans.) Соёмбо, Улаанбаатар. (Han shu. History of the Huns. 94.). (In Mongolian)

Batjargal (2016b). Хожуу Хан улсын бичиг. 89. Өмнөд Хүннүгийн намтар. Соёмбо, Улаанбаатар. (Batjargal, Trans.) (Hou Han shu. History of the Southern Huns. 89.). (In Mongolian)

\footnotetext{
${ }^{42}$ The division of the Hunnic state administration has modified from the 2 nd century BC. Shi Ji doesn't mention the title shuo pang wang, du lu wang, luo wang, and the an le wang title. The structure remained and both of the Southern Huns, who were the close relatives of the royal clan.
} 
Batjargal (2017). Жин улсын бичиг. 97. Бейди Хүннүгийн намтар. (Batjargal, Trans.) Соёмбо, Улаанбаатар. (Jin shu 97. History of the four foreigners. Beidi Huns). (In Mongolian)

Boodberg, P. (author) \& Cohen A. P. (ed.). (1979). Selected Works of Peter A. Boodberg. Berkeley: University of California Press. (In Mongolian)

Chronica Pictum (1976). Hungarian Chronicle with pictures. (Bellus, Trans). Budapest: Európa Könyvkiadó,.

Crespigny, R. (2006). Some Notes on the Western Regions in Later Han. Journal of Asian History, 40(1), 1-30.

Crespigny, R. (2010). Imperial warlords. A Biogrraphy of Cao Cao. (155-220 AD). Leiden-Boston: Sinica Leidensia..

Csongor, B. (1993). Kínai források az ázsiai avarokról [Chinese sources on the Avars of Asia]. Történelem és kultúra [History and culture], (9). (In Hungarian)

Grousset, R. (1970). The Empire of the Steppes. A History of Central Asia. Translated from the French by Naomi Walford. Rutgers University Press, New Jersey.

Hyun, J. K. (2015). The Huns. Peoples of the Ancient World. Routledge. London

Iishjamts, N. (1994). Nomads in Eastern Central Asia. In Jano Harmatta (Eds.). History of Civilization of Central Asia Vol. II. (pp. 151-171). Paris: Unesco Publishing.

Lee, Ch.- Linhu Zh. (2011). Xiongnu Population History in Relation to China, Manchuria, and the Western Regions. In Ursula Brosseder, Bryan K. Miller (Eds.), Xiongnu Archaeology. Xiongnu Archaeology Multidisciplinary Perspectives of the First Steppe Empire in Inner Asia (pp. 193-201). Vor- und Frühgeschichtliche Archäologie Rheinische Friedrich-Wilhelms-Universität Bonn.

Liu, Sh. (2001).Ethnicity and the Suppression of Buddhism in Fifth-Century China: The Background and Significance of the Gaowu Rebellion. Bulletin of the Institute of history and philology. Academia Sinica, 72(2), 1-48.

Luo, G. (1999). The Three Kingdoms. A Historical Novel. (Moss R. Trans.) Berkeley: University of California.

Ma, L. Q. (2004). Yuan xiong-nu, xiong nu. Nei Meng guo Da Xue, Huhehaote

Marks, R. (2011). China: An Environmental History. Rowman \& Littlefield Publishers.

Obrusánszky, B. (2016). Attila, Európa ura. Barót: Tortoma Kiadó,

Pritsak, O. (1954). Die 24 Ta-ch'en zur Geschichte des Verwaltungsaufbaus der Hsiung-nu Reiche. In: Oriens Extremus, Jg. I, H. 2, 178-202.

Sneath, D. (2007). The Headless State. Aristocratic Orders, Kinship, Society and Misrepresentation of Nomadic Inner Asia. Columbia University Press. New York.

Turbat, Ts. (2013). Encyclopaedia Xiongnu. Institute of Archaeology. Mongolian Academy of Sciences, Ulaanbaatar

Twitchett- Loewe (1995). The Cambridge History of Ancient China: From the Origins of Civilization to 221 BC. 3rd edition. Cambridge University Press. Cambridge. 
Uchralt (2015). Hunnu helniy sudlal. Jikom. Ulaanbaatar.

Xiong, V. C. (2009). Historical Dictionary of Medieval China. The Scarecrow Press. Lanham, Maryland, Plymouth

Watson, B. (1961). Records of the Grand Historian of China. Translated from the Shihchi of Ssu-ma-Chien. New York-London, I-II.

\section{Список литературы}

Batjargal (2016а). Хан улсын бичиг. Хүннүгийн шастир. 94. (Batjargal, Trans.) Coёмбо, Улаанбаатар. (Han shu. History of the Huns. 94.). (In Mongolian)

Batjargal (2016b). Хожуу Хан улсын бичиг. 89. Өмнөд Хүннүгийн намтар. Соёмбо, Улаанбаатар. (Batjargal, Trans.) (Hou Han shu. History of the Southern Huns. 89.). (In Mongolian)

Batjargal (2017). Жин улсын бичиг. 97. Бейди Хүннүгийн намтар. (Batjargal, Trans.) Соёмбо, Улаанбаатар. (Jin shu 97. History of the four foreigners. Beidi Huns). (In Mongolian)

Boodberg, P. (author) \& Cohen A. P. (ed.). (1979). Selected Works of Peter A. Boodberg. Berkeley: University of California Press. (In Mongolian)

Chronica Pictum (1976). Hungarian Chronicle with pictures. (Bellus, Trans). Budapest: Európa Könyvkiadó,.

Crespigny, R. (2006). Some Notes on the Western Regions in Later Han. Journal of Asian History, 40(1), 1-30.

Crespigny, R. (2010). Imperial warlords. A Biogrraphy of Cao Cao. (155-220 AD). Leiden-Boston: Sinica Leidensia..

Csongor, B. (1993). Kínai források az ázsiai avarokról [Chinese sources on the Avars of Asia]. Történelem és kultúra [History and culture], (9). (In Hungarian)

Grousset, R. (1970). The Empire of the Steppes. A History of Central Asia. Translated from the French by Naomi Walford. Rutgers University Press, New Jersey.

Hyun, J. K. (2015). The Huns. Peoples of the Ancient World. Routledge. London

Iishjamts, N. (1994). Nomads in Eastern Central Asia. In Jano Harmatta (Eds.). History of Civilization of Central Asia Vol. II. (pp. 151-171). Paris: Unesco Publishing.

Lee, Ch.- Linhu Zh. (2011). Xiongnu Population History in Relation to China, Manchuria, and the Western Regions. In Ursula Brosseder, Bryan K. Miller (Eds.), Xiongnu Archaeology. Xiongnu Archaeology Multidisciplinary Perspectives of the First Steppe Empire in Inner Asia (pp. 193-201). Vor- und Frühgeschichtliche Archäologie Rheinische Friedrich-Wilhelms-Universität Bonn.

Liu, Sh. (2001).Ethnicity and the Suppression of Buddhism in Fifth-Century China: The Background and Significance of the Gaowu Rebellion. Bulletin of the Institute of history and philology. Academia Sinica, 72(2), 1-48.

Luo, G. (1999). The Three Kingdoms. A Historical Novel. (Moss R. Trans.) Berkeley: University of California. 
Ma, L. Q. (2004). Yuan xiong-nu, xiong nu. Nei Meng guo Da Xue, Huhehaote

Marks, R. (2011). China: An Environmental History. Rowman \& Littlefield Publishers.

Obrusánszky, B. (2016). Attila, Európa ura. Barót: Tortoma Kiadó,

Pritsak, O. (1954). Die 24 Ta-ch'en zur Geschichte des Verwaltungsaufbaus der Hsiung-nu Reiche. In: Oriens Extremus, Jg. I, H. 2, 178-202.

Sneath, D. (2007). The Headless State. Aristocratic Orders, Kinship, Society and Misrepresentation of Nomadic Inner Asia. Columbia University Press. New York.

Turbat, Ts. (2013). Encyclopaedia Xiongnu. Institute of Archaeology. Mongolian Academy of Sciences, Ulaanbaatar

Twitchett- Loewe (1995). The Cambridge History of Ancient China: From the Origins of Civilization to 221 BC. 3rd edition. Cambridge University Press. Cambridge.

Uchralt (2015). Hunnu helniy sudlal. Jikom. Ulaanbaatar.

Xiong, V. C. (2009). Historical Dictionary of Medieval China. The Scarecrow Press. Lanham, Maryland, Plymouth

Watson, B. (1961). Records of the Grand Historian of China. Translated from the Shihchi of Ssu-ma-Chien. New York-London, I-II. 